\title{
PANGAN MIKOPROTEIN UNTUK PERTUMBUHAN BALITA DALAM MENANGGULANGI STUNTING
}

\author{
Yayan Maryana $^{1}$, Nindya Sekar Mayuri ${ }^{2}$, Ayu Asifadilah ${ }^{3}$, Nyoman P. A \\ ${ }^{1}$ Farmasi / Politeknik Meta Industri / yayan_maryana@yahoo.co.id \\ ${ }^{2}$ Farmasi / Politeknik Meta Industri / nindya@politeknikmeta.ac.id \\ ${ }^{3}$ Farmasi / Politeknik Meta Industri / ayuasifadilah@yahoo.com \\ ${ }^{4}$ SITH / Institusi Teknologi Bandung / nyoman@sith.itb.ac.id
}

\begin{abstract}
The purpose of this study was to determine the effect of mycoprotein in stunting. The study used a randomized controlled trial (RCT) method using Mus musculus in 4 treatment where each treatment was given Pleurotus ostreatus, Volvariella volvacea, commercial feed and rice. The protein content of the Pleurotusostreatus is $9.35 \%$ while the Volvariella volvaceais $11.34 \%$. Mycoprotein increases the average body weight of Mus musculus(Pleurotus ostreatus 24.5 29.39 grams and Volvariella volvacea 25.93 - 30.83 grams) and for mushrooms that can increase the average body weight of baby Mus musculusare is a Pleurotus ostreatus $(0,14$ 0.88 grams) by influencing the weight loss of the bile $(0.1 \mathrm{gram})$ and increasing the number of baby Mus musculus(0.7 Mus musculus).
\end{abstract}

Keywords: Stunting, Pleurotus ostreatus and Volvariella volvacea

\begin{abstract}
ABSTRAK
Tujuan penelitian ini adalah untuk mengetahui pengaruh mikoprotein dalam menanggulangi stunting. Penelitian menggunakan metode Randomized Controlled Trial (RCT) dengan menggunakan Mus musculus pada 4 perlakuan dimana setiap perlakukan diberi Pleurotusostreatus, Volvariella volvacea, pakan komersil dan nasi. Kandungan protein pada produk Pleurotus ostreatus adalah 9,35\% sedangkan Volvariella volvacea adalah 11,34\%. Mikoprotein meningkatkan rata-rata berat badan induk Mus musculus (Pleurotusostreatus 24,529,39 gram dan Volvariella volvacea 25,93-30,83gram) dan untuk jamur yang mampu meningkatkan rata-rata berat badan bayi Mus musculus adalah Pleurotus ostreatus $(0,14-0,88$ gram) dengan mempengaruhi pengurangan berat empedu ( 0,1 gram) dan mengingkatkan jumlah bayi Mus musculus(0,7ekor).
\end{abstract}

Kata kunci: Stunting, Pleurotus ostreatus dan Volvariella volvacea

\section{LATAR BELAKANG}

Proses pertumbuhan yang dialami oleh anak merupakan hasil kumulatif sejak anak tersebut dilahirkan. Keadaan gizi yang baik pada masa balita merupakan fondasi penting bagi kesehatan anak tersebut di masa depan. Kondisi yang berpotensi mengganggu pemenuhan protein pada anak akan menyebabkan masalah gangguan pertumbuhan diantaranya adalah stunting (Dewey dkk, 2008). Stunting merupakan suatu keadaan dimana tinggi badan anak yang terlalu rendah. Stunting atau terlalu pendek berdasarkan umur adalah tinggi badan yang berada di bawah minus dua standar deviasi $(<-2 \mathrm{SD})$ dari tabel status gizi WHO child growth standar (Victora dkk, 2010).

Stunting pada balita merupakan masalah gizi utama di Indonesia dimana pada tahun 2016 terjadi sebesar 27,5\% dan pada tahun 2017 mengalami kenaikan menjadi 29,6\%. Berdasarkan data pemantauan status gizi (PSG), kejadian balita stunting memiliki prevalensi tertinggi dibandingkan dengan masalah gizi lainnya seperti gizi kurang, kurus, dan gemuk (Kementerian 
Kesehatan RI, 2018). Salah satu faktor yang mempengaruhi pertumbuhan anak adalah asupan protein (Habestreit dkk, 2016). Disisi lain, pemberian asupan protein yang berlebih berpotensi obesitas (Syrad dkk, 2016).

Mikoprotein adalah bahan makanan yang berasal dari jamur dan mengandung protein serta serat tinggi namun rendah kolesterol sehingga mengkonsumsi produk mikoprotein bagi balita dapat memenuhi asupan protein tanpa khawatir akan terjadinya obesitas (Mattila dkk., 2001; Barros dkk., 2008). Penelitian ini bertujuan untuk mengetahui pengaruh mikoprotein dalam menanggulangi stunting, adapun parameter yang diamati terdiri dari pengukuran kandungan protein jamur, berat badan, jumlah anakan dan berat organ mencit.

\section{METODE PENELITIAN}

Penelitian menggunakan menggunakan desain Experimen murni RCT. Hewan uji yang digunakan berupa mencit betina yang sedang hamil yang dibagi dalam 4 kelompok perlakuan yang terdiri dari kelompok 1 diberi pakan Jamur tiram, kelompok 2 pakan Jamur merang, kelompok 3 pakan komersil dan kelompok 4 pakan nasi putih.

Pemberian pakan dilakukan setiap hari sebanyak 20\%/BB dan air minum diberikan secara ad libitum. Untuk kelompok yang diberikan pakan Jamur, pakan Jamur yang diberikan dengan cara dihaluskan dan dikombinasikan dengan pakan komersil dengan perbandingan 90:10. Pemberian pakan dilakukan selama masa kehamilan sampai usia sapih.

Parameter yang diamati terdiri dari pengukuran kandungan protein jamur, berat badan, jumlah anakan dan berat organ mencit. Pengukuran kandungan protein jamur dilakukan dengan metode kjehdahl. Penimbangan berat badan induk mencit dilakukan selama masa kehamilan sampai masa menyusui, sedangkan pada bayi mencit dilakukan selama masa menyusui. Perhitungan jumlah bayi mencit dilakukan dengan menghitung jumlah bayi mencit yang hidup sedangkan penimbangan berat organ yang terdiri dari hati, ginjal dan empedu yang diperoleh dari pembedahan induk mencit dari masing-masing kelompok pada tahap akhir penelitian. Adapun data diolah menggunakan Excel.

\section{HASIL DAN PEMBAHASAN}

\section{Kandungan Protein Jamur}

Tabel 1. Kandungan protein jamur

\begin{tabular}{llc}
\hline No & \multicolumn{1}{c}{ Jamur } & Kandungan Protein (\%) \\
\hline 1 & Jamur tiram & $9,35 \%$ \\
2 & Jamur merang & $11,34 \%$ \\
\hline
\end{tabular}

Kandungan protein yang paling tinggi diperoleh dari Jamur merang $(11,34 \%)$ kemudian diikuti oleh Jamur tiram $(9,35 \%$.). Perbedaan kandungan protein ini disebakan karena media yang digunakan pada pertumbuhan kedua Jamur tersebut berbeda yaitu Jamur merang ditumbuhkan pada media merang sedangkan Jamur tiram ditumbuhkan pada media serbuk kayu. 


\section{Berat Badan Induk Mencit}

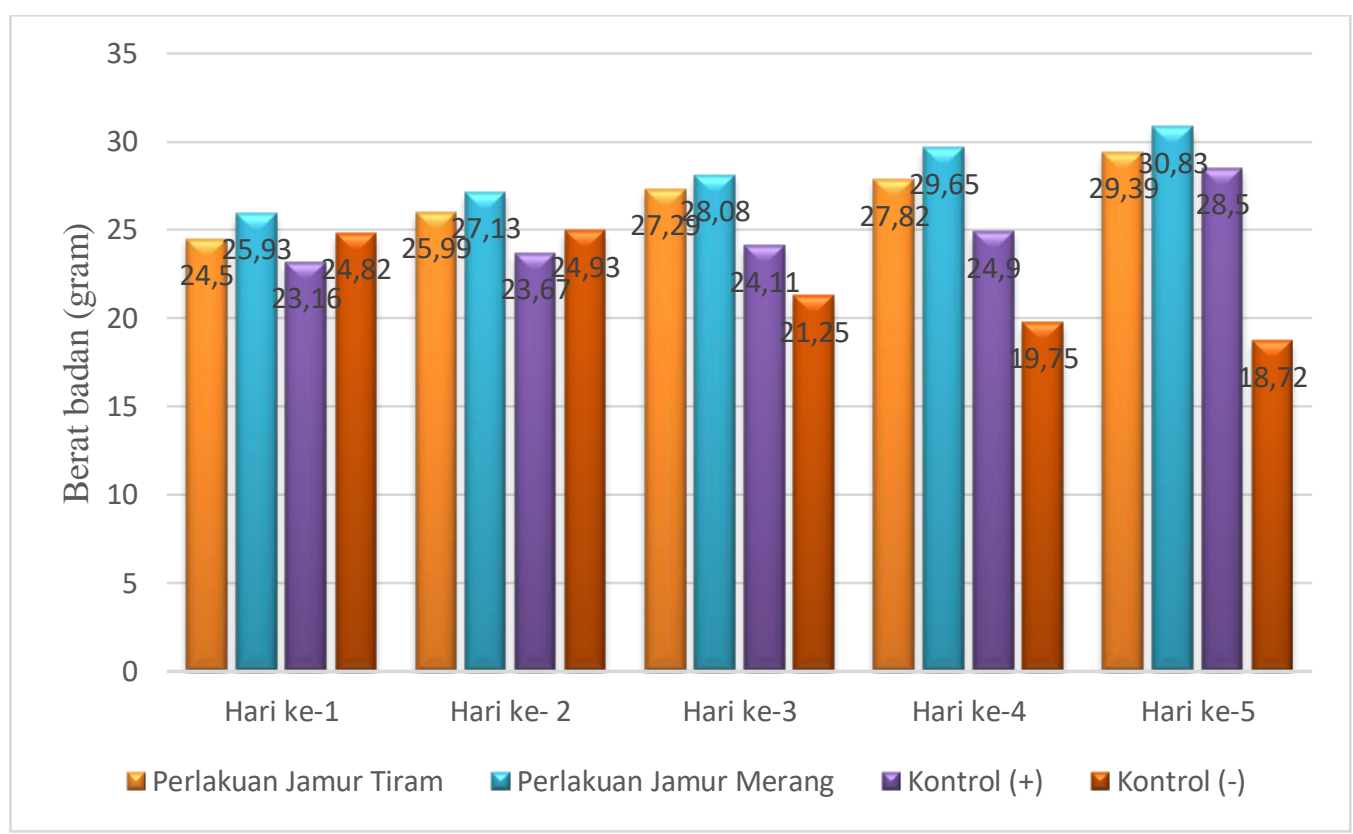

Gambar 1. Berat badan induk mencit

Pada perlakukan pemberian pakan mikropotein terdapat kenaikan rata-rata berat badan induk mencit lebih tinggi jika dibandingkan dengan kontrol. Pada perlakuan Jamur tiram terdapat kenaikan dari 24,5 gram sampai 29,39 gram, Jamur merang dari 25,93 gram sampai 30,83 gram, kontrol (+) dari 23,16 gram sampai 28,5 gram dan kontrol (-) dari 24,82 gram sampai 18,72 gram. Peningkatan berat badan ini disebabkan karena Jamur tiram dan Jamur merang memiliki kandungan gizi yang lengkap seperti protein, karbohidrat, serat, dan vitamin (Yuliani dkk., 2018).

\section{Berat Badan Bayi Mencit}

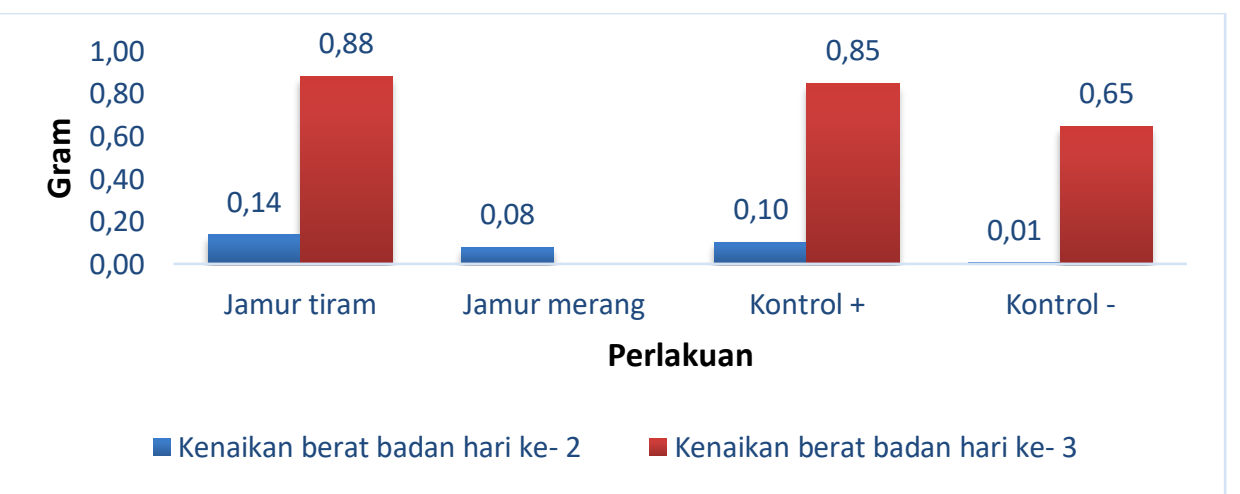

Gambar 2. Berat badan bayi mencit

Berdasarkan grafik yang tertera pada Gambar 2. dapat dilihat bahwa pemberian pakan pada masing-masing perlakuan memberikan pengaruh yang berbeda terhadap peningkatan rata-rata berat badan bayi mencit. Jika dibandingkan dengan kelompok lain, kelompok bayi mencit yang berat badannya paling tinggi adalah kelompok Jamur tiram yaitu sebesar 0,14 gram di hari ke-2 dan sebesar 0,88 gram di hari ke-3. Sedangkan kelompok yang tingkat pertumbuhannya paling 
rendah adalah kelompok kontrol (-) dengan berat badan sebesar 0,01 gram di hari ke-2 dan sebesar 0,65 gram di hari ke-3. Untuk kelompok Jamur merang tidak diperoleh data yang lengkap karena bayi mencit mangalami kematian.

Kadar protein yang tinggi pada Jamur tiram dapat menjadi penyebab terjadinya peningkatan berat badan bayi mencit pada kelompok ini. Nilai tinggi protein yang dimiliki Jamur tiram memiliki kualitas lebih baik karena mengandung protein lengkap dengan distribusi asam amino esensial dan non-esensial yang baik dibandingkan beberapa biji polongan (Khan dkk., 2010). Evaluasi protein juga telah menunjukkan bahwa protein Jamur tiram memiliki kandungan yang lebih tinggi dibandingkan sayuran berdaun hijau (Adebayo dkk., 2014). Protein tersusun atas asam amino dimana utama asam amino yaitu sebagai pengatur jalur metabolisme, pertumbuhan dan perkembangan organisme (Wu, 2019). Adapun pada perlakukan Jamur merang dikarenakan ditumbuhkan pada media merang sehingga memungkinkan protein tidak dapat diserap secara maksimal sehingga tidak dapat meningkatkan pertumbuhan berat badan bayi mencit atau bahkan tidak dapat dicerna sehingga mengakibatkan kematian pada mencit.

\section{Berat Hati, Empedu dan Ginjal Induk Mencit}

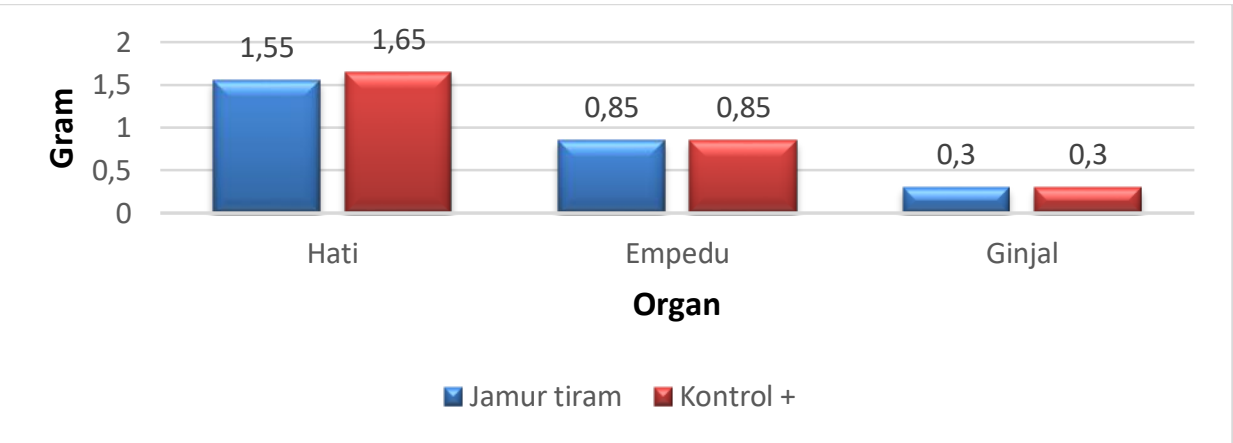

Gambar 3. Berat hati, empedu dan ginjal induk mencit

Berdasarkan grafik pada Gambar 3 menunjukkan bahwa perbedaan rata-rata berat organ antara kelompok mencit perlakuan Jamur tiram dan kontrol (+) terjadi pada organ hati, dengan berat sebesar 1,55 gram pada kelompok Jamur tiram dan sebesar 1,65 gram pada kelompok kontrol (+). Sedangkan pada perlakukan empedu $(0,85$ gram $)$ dan ginjal $(0,3$ gram $)$ tidak terdapat perbedaan rata-rata berat organ induk mencit antara perlakukan mikoprotein dengan kontrol.

Hati mempunyai peran dalam metabolisme protein, yaitu dalam proses deaminasi (mengubah asam amino menjadi amoniak) agar dapat digunakan sebagai energi. Oleh karena itu, tingginya kadar protein pada Jamur tiram menyebabkan kerja hati lebih keras dalam mensintesis protein dibandingkan kontrol.

\section{Jumlah Bayi Mencit}

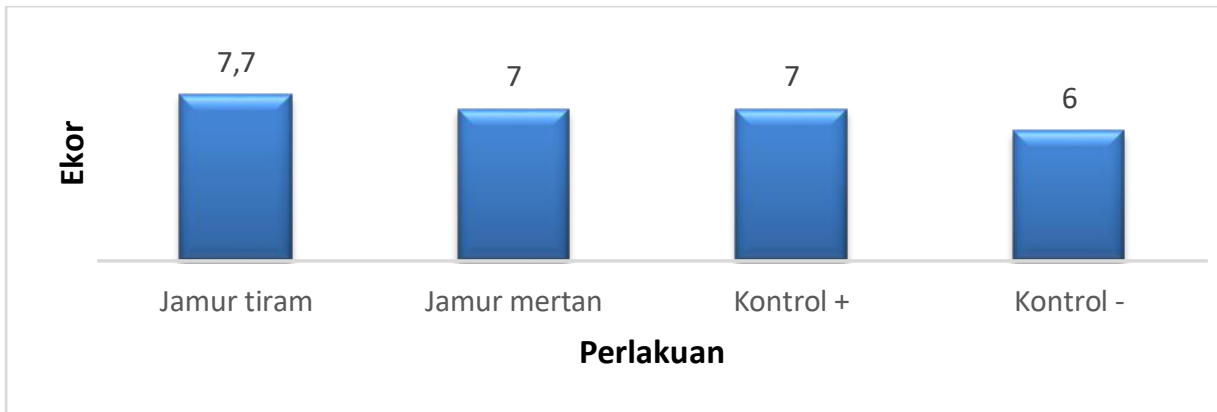


Gambar 4. Jumlah bayi mencit

Berdasarkan grafik yang tertera pada gambar 4. dapat dilihat bahwa kenaikan rata-rata jumlah bayi mencit paling tinggi dialami oleh kelompok Jamur tiram dengan jumlah bayi sebanyak 7,7 ekor. Sedangkan kenaikan rata-rata jumlah bayi mencit paling rendah dialami oleh kelompok kontrol (-) yaitu sebanyak 6 ekor.

Sampai saat ini belum terdapat literatur terkait pengaruh pemberian pangan mikoprotein terhadap jumlah anakan mencit akan tetapi berdasarkan data diatas terdapat kemungkinan pengaruh pemberian pakan Jamur tiram terhadap jumlah anakan mencit.

\section{PENUTUP}

\section{Kesimpulan}

Berdasarkan penelitian ini dapat disimpulkan bahwa Jamur tiram mampu meningkatkan ratarata berat badan bayi mencit sehingga berpotensi sebagai salah satu produk mikoprotein yang mampu mencegah stunting.

\section{Saran}

Perlu dilakukan penelitian lebih lanjut terkait penggunaan tubuh buah Jamur tiram putih (Fase Generatif) sebagai produk mikoprotein.

\section{DAFTAR PUSTAKA}

Adebayo, E.A., Oloke, J.K., Azeez, M.A., Omomowo, I.O., Bora, T.C. 2014. Assessment of the genetic diversity among ten genotypes of Pleurotus (oyster mushroom) using nutrient and mineral compositions. Sci. Horticult.,166, 59-64.

Dewey KG, Adu-Afarwuah S.2008. Systematic review of the efficacy and effectiveness of complementary feeding interventions in developing countries. Matern Child Nutr, 4 Suppl 1:24-85.

Hebestreit A, Barba G. 2016. Cross -Sextional and Longitudinal Associations Energy Intake and BMI Z Score In European Children. International Journal of Behavioral Nutrition anh Physian 13.

H, Syrad, C. H Llewellyn and J. Wardle. 2016. Energy and nutrient intakes of young children in the UK: findings from the Gemini twin cohort. British Journal of Nutrion 115(10): 18431850.

Kementerian Kesehatan RI. 2018. Buku Saku Pemantauan Status Gizi Tahun 2017. Jakarta.

Khan, M.A., Tania, M., Zhang, D., Chen, H. 2010. Antioxidant enzymes and cancer. Chin J Cancer Res., 22:87-92.

L. Barros, D. M. Correia, I. C. F .R . Ferreira, P. Baptista, and C. Santos-Buelga. 2008. Optimization of the determination of tocopherols in Agaricus sp. edible mushrooms by a normal phase liquid chromatographic method. Food Chemistry, vol. 110, no.4, pp. 10461050.

P. Mattila, K. Könkö. M. Eurola. 2001. Contents of vitamins, mineral elements, and some phenolic compounds in cultivated mushroom," Journal of Agricultural and Food Chemistry, vol. 49, no. 5, pp. 2343-2348.

Victora CG, de Onis M, Hallal PC, Blössner M, Shrimpton R. Worldwide. 2010. Timing of growth faltering: revisiting implications for interventions. Pediatrics 125(3); e473-e480.

Wu, G. 2009. Amino acids: metabolism, functions, and nutrition. Amino Acids, 37, 1-17.

Yuliani, Y., Maryanto, M., dan Nuarhayati, N. 2018. Karakteristik Fisik dan Kimia Tepung Jamur Merang dan Tepung Jamur Tiram Tervariasi Perlakukan Blansing. Jurnal Agroteknologi 12(02). 